\title{
Histopathological effect of powder detergent on the livers of laboratory mice Mus musculus
}

\author{
Sundus M. Tayfur ${ }^{1}$, Ayoub A. Al-bayti ${ }^{1}$, Asmaa M. Al-bayati ${ }^{1}$ \\ Muhammedsundus4@gmail.com, ayoub.ali77@ntu.edu.iq, asmaa.albayati@ntu.edu.iq \\ ${ }^{1}$ Northern Technical University, Technical College-Kirkuk -Medical Laboratory Techniques \\ Department.
}

\begin{abstract}
,
The powder detergents are one of the chemical substances using in daily life. Like other chemical substances, detergents have detrimental effects on the human body. Therefore, the impact of powder detergent was tested in this study. The pathological effects of powder detergent on the liver were investigated by ingesting 80 mice Mus musculus strain with detergent solution. Mice were divided into (8) groups. The control group was ingested vegetables (celery) only, while the groups were ingested celery which soaked in the aqueous solution of powder detergent with various concentrations at the different times $(1.5 \mathrm{~g} / \mathrm{Kg}$ for $15 \mathrm{~min}, 3 \mathrm{~g} / \mathrm{Kg}$ for $15 \mathrm{~min}, 4.5 \mathrm{~g} / \mathrm{Kg}$ for $15 \mathrm{~min}, 1.5 \mathrm{~g} / \mathrm{Kg}$ for $30 \mathrm{~min}, 3 \mathrm{~g} / \mathrm{Kg}$ for $30 \mathrm{~min}, 4.5 \mathrm{~g} / \mathrm{Kg}$ for $30 \mathrm{~min}, 1.5 \mathrm{~g} / \mathrm{Kg}$ for $1-2 \mathrm{~min})$. The livers of the mice in ingested groups showed marked histopathological changes included cloudy swelling and infiltration of mononuclear inflammatory cells. Additionally, vascular congestion and hepatocellular necrosis as indicated by karyolysis with narrowing of the sinusoids. Considerable nuclear pyknosis, karyorrhexis, marked hydropic degeneration associated with Kupffer cell hyperplasia. Extending of injuries increased with rising the concentration and duration of exposure to the detergents. The results of the study emphasize the health hazards for exposure to the detergent, so a reasonable approach to tackle this issue could be by proper handling and disposal the detergents during daily life using.
\end{abstract}

Keywords: Histopathological changes, Detergents, mice, liver, Necrosis, degeneration, hepatocyte.

\section{$\underline{\text { Introduction }}$}

The detergents are the substances that help to remove dirt like fats from contaminated surfaces and bodies. Detergents can be classified for instance according to their chemical constitution to the polar and nonpolar groups such as (glucosides, alkyl ionic detergents, polyoxyethylene alcohols, bile salts, sulphonates, etc.), and to the charge character groups like (anionic, cationic, zwitterionic = amphoteric and nonionic). Moreover, detergents also classified as a mild or strong detergent in terms of their ability for solubilizing and/or for denaturation of the proteins [1]. In general, all detergents are soluble amphipathic 'amphiphilic' compounds, with both lipophilic (hydrophobic, nonpolar) and lipophobic (hydrophilic, polar) sites within one molecule [2]. The aromatic compound was later replaced by a compound linear alkyl-type, and detergent production is as efficient as the former kind in its detergent action, and it is more biodegradable and soluble [3].

The detergents excessively used in both industry and household for cleaning heavy-duty machines, equipment, vehicles and installations. As a consequence detergent can leave some traces of its chemical compounds taken up by the ingestion of food, drinking water, dermal absorption and oral exposure to the detergent [4]. Thus, these might lead to alimentary canal disorders such as vomiting, diarrhea and metabolic distress. In another significant study, Ogundiran [5] found that inappropriate 
washing of materials and foods with the detergents show haematological responses to toxicants and can cause tissue damage in the gills, livers, heart, kidney and epidermis of animals. As a result, it leads to an increase in domestic health hazards and the pollution of the environment [6]. Most people handle and dispose of detergents without precaution due to a lack of information about the toxicity of detergents that lead to most health hazards. Therefore, a thorough investigation of the health risks and ecological disorders needs to be done to determine these effects that arise from improper handling and disposal of detergents. In worldwide, governments are making aforethought efforts by holding policies, environmental conferences and conventions to keep environments free from pollutants through. This has become needful because presently, there is no alternative to detergent. Consequently, the Federal Government in many countries establishes the rules for sufficient human and ecological protections in any technological and socio-economic strictly development need industrial operators for controlling the effects of their waste products [7].

Although many countries stated allegation for environmental and ecological impacts, only a few detergents have been tested ecologically for safety [5]. Despite the detergent certainly poses health risks for humans and animals, but the doubt lies in the mechanical actions of these detergents and how dangerous it is [8]. The careful handling and disposal of detergent by the accurate methods are essential in the reduction of the diseases and toxicity that developed from using the detergents. Additionally, using alternative biological substances such as microbial lipase during the production of the detergents is an important new technique for reducing the mass of toxic materials found in detergents [9]. Although some researchers described the effects of detergents on the animals and plants based on spirometry or radiology or both methods; but an in-depth analysis of the impact of detergent exposure on various organs and systems in humans or animals has not published. Therefore, the present study aims to clarify the danger of using cleaning powders excessively in washing or macerating vegetables to ensure cleaning them.

\section{Materials and Methods:}

\section{Test Materials:}

The detergent used in this study collected from the local supermarkets, and it included the chemical constituents that are Anionic surfactants, Non-ionic surfactants, Methylisothiazolinone, sodium sulfate, sodium carbonate, Phenoxyethanol, phosphate, poly-carboxylates and enzymes.

\section{Animal management}

Healthy, adult mice of Mus musculus strain ranging in age between (4-8) weeks old and their weight $(25 \pm 2 \mathrm{~g})$ were used in this study. These animals were housed under standard conditions of temperature $\left(22-24{ }^{\circ} \mathrm{C}\right)$, for $(12 / 12)$ hours of daylight cycle. Animals were housed in cages (dimensions $29 \times 15 \times 12 \mathrm{~cm} 2$ ). Water and feed containing pellet feed and Celery were freely excesses and animals were kept for at least one week for adaptation. Animal cages were cleaned and sterilised with $70 \%$ ethanol alcohol once a week regularly according to the procedure mentioned by Ojo and his colleagues [10].

\section{Experimental Design:}

The detergent management protocol (the concentration, route of administration and interval of administration) was followed according to the standard procedure [11] [12]. Animals were divided randomly into eight groups A, B , C, D, E , F and G (each group 10 mice). The control group $(\mathrm{H})$ supplied with standard pellet feed and Celery, while the other seven groups ingested with pellet feed and Celery that soaked in different concentrations of detergent solution at different time points and duration (Table 1). All mice were killed after (18 weeks) of begging the experiment by cervical dislocation and decapitation method. Livers were removed immediately, immersed rapidly in $10 \%$ formalin and stored at $4^{\circ} \mathrm{C}$ overnight. 
Table1. Detergent administration protocol

\begin{tabular}{ccccc}
\hline $\begin{array}{c}\text { Group } \\
\text { number }\end{array}$ & Number of mice & $\begin{array}{c}\text { concentration of detergent } \\
/ \text { does }(\mathrm{g} / \mathrm{Kg})\end{array}$ & $\begin{array}{c}\text { Exposure time } \\
(\text { minute) }\end{array}$ & $\begin{array}{c}\text { Time of } \\
\text { Autopsy /week }\end{array}$ \\
\hline $\mathrm{A}$ & 10 & 1.5 & 15 & After 18 \\
$\mathrm{B}$ & 10 & 3 & 15 & After 18 \\
$\mathrm{C}$ & 10 & 4.5 & 15 & After 18 \\
$\mathrm{D}$ & 10 & 1.5 & 30 & After 18 \\
$\mathrm{E}$ & 10 & 3 & 30 & After 18 \\
$\mathrm{F}$ & 10 & 4.5 & 30 & After 18 \\
$\mathrm{G}$ & 10 & 1.5 & $1-2$ & After 18 \\
$\mathrm{H}$ & 10 & Non treated & Non treated & After 18 \\
\hline control) & 10 & &
\end{tabular}

\section{Histological assessment:}

Fixed Fragments of liver tissue were blocked in paraffin, cut, and stained with hematoxylin and eosin (H\&E) stains. In total 20 slides were made for each group (two sections from each animal were collected). The following histological variables such as swelling hepatocytes, distribution of polymorph nuclear, fatty degenerations (FD) and vascular congestion (C), as well as the inflammatory, infiltrate and zonal distribution were assessed by a blinded experienced pathologist. The sections were examined under the light microscope (Optika, Italy) and coupled to an Optika Vision-Lite digital camera for running spot for Windows [13].

\section{Results:}

Representative sections of liver tissues from mice with normal livers in Figure 1. showed the normal functional lobules which consist of cords of polygonal hepatocytes arranged in a radial pattern around a central vein. The sinusoids can be seen between the cords and endothelial-lined spaces through which blood passes. The results of the histopathological diagnosis of the liver in the groups exposed to the different concentrations and time points of detergent showed marked histological changes. Strikingly, assessment of the livers in the groups' A, E, and G showed marked cloudy swelling with pallor cytoplasm and infiltration of mononuclear inflammatory cells due to hydropic degeneration (Figures 2, 5 and 7).

From the data in Figures 3, 4, and $\mathbf{9}$ it is apparent that the livers in groups A, D and C suffered from hepatocellular necrosis as indicated by karyolysis of the necrotic cell associated with narrowing of the sinusoids. There was dilation of central vein with considerable nuclear pyknosis, karyorrhexis and marked hepatocellular cytoplasmic vacuolation (hydropic degeneration) (Figures 3, 4, 6, 7, 10 and 11). Furthermore, the trated groups B, C, D, E and F showed focal aggregation of inflammatory cells, ballooning degeneration associated with blood vessel congestion. Finally, group ingested with a high concentration of detergent showed Kupffer cell hyperplasia associated with phagocytosis of the necrotic hepatocytes (Figures 5, 7 and 8). 


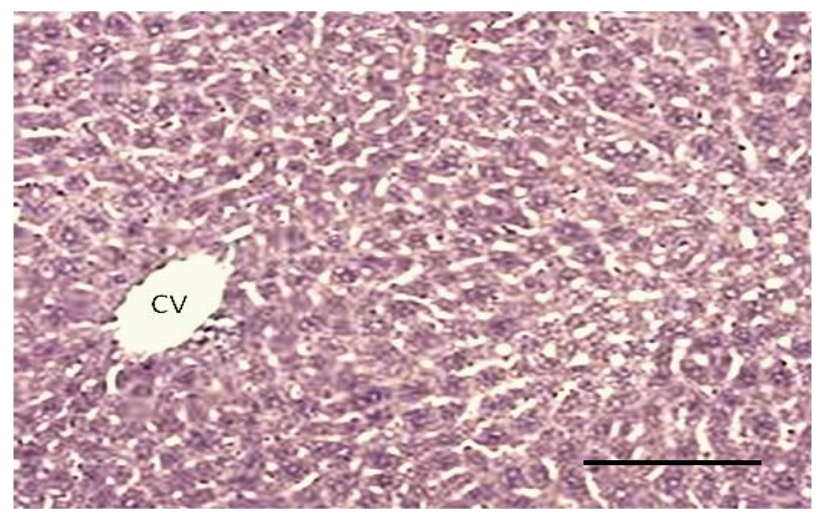

Fig.1. Photomicrograph of a liver section from the control group showing normal hepatic lobule consisting of normal hepatocytes, sinusoids and central vein $(\mathrm{CV})$. (H\&E, Scale Bar $=100 \mu \mathrm{m})$.

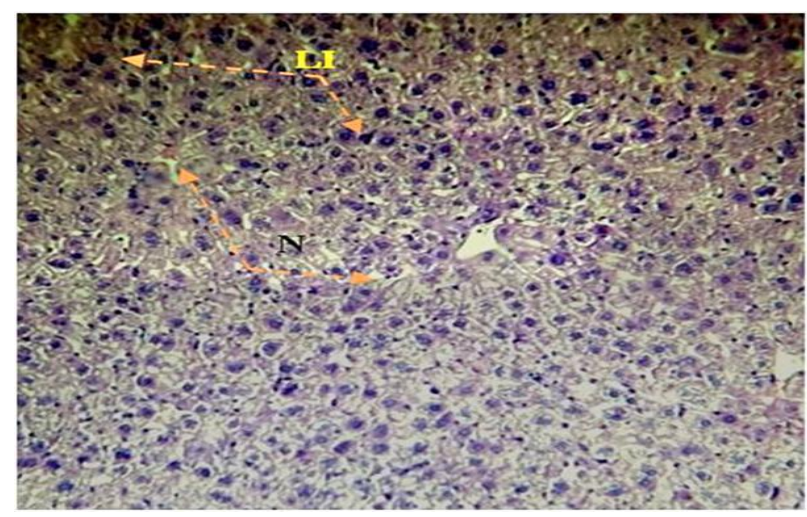

Fig.2. Photomicrograph of a liver section from the detergenttreated group (1.5 g/Kg for $15 \mathrm{~min})$ showing marked necrosis $(\mathrm{N})$ and infiltration of mononuclear inflammatory cells mainly lymphocytes (LI), (H\&E, 20X).

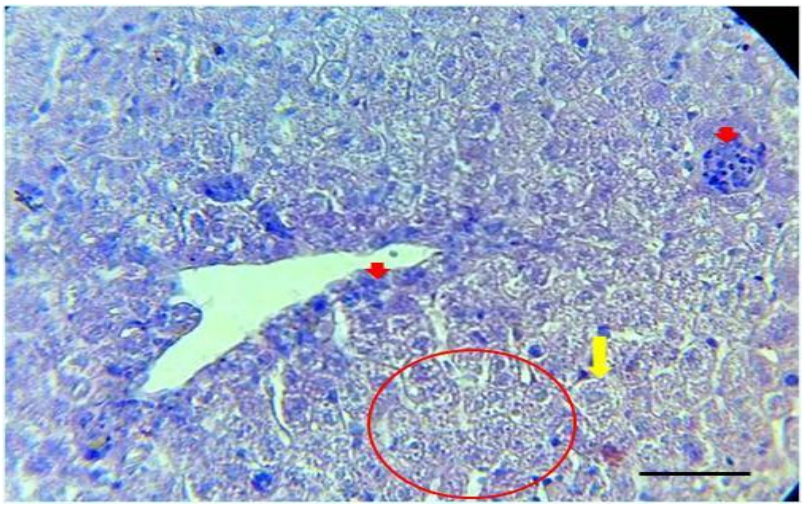

Fig.3. Photomicrograph of a liver section from the detergenttreated group $(1.5 \mathrm{~g} / \mathrm{Kg}$ for $15 \mathrm{~min})$ showing hepatocellular necrosis (red circle) as indicated by karyolysis of the necrotic cells and marked cloudy swelling associated with narrowing of the sinusoids. (H\&E, Scale Bar= 50 $\mu \mathrm{m}$ ). 


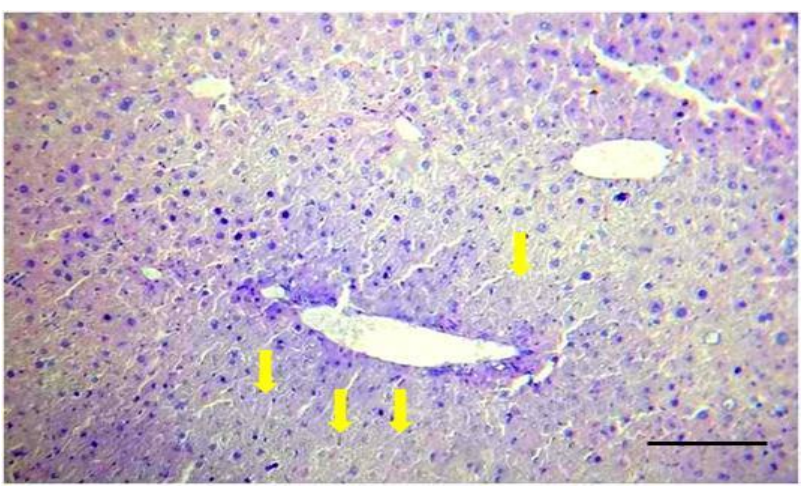

Fig.4. Photomicrograph of a liver section from the detergenttreated group $(1.5 \mathrm{~g} / \mathrm{Kg}$ for $30 \mathrm{~min})$ showing marked hepatocellular necrosis (yellow arrows) as indicated by the nuclear pyknosis, karyorrhexis and karyolysis (H\&E, Scale Bar $=100 \mu \mathrm{m})$.

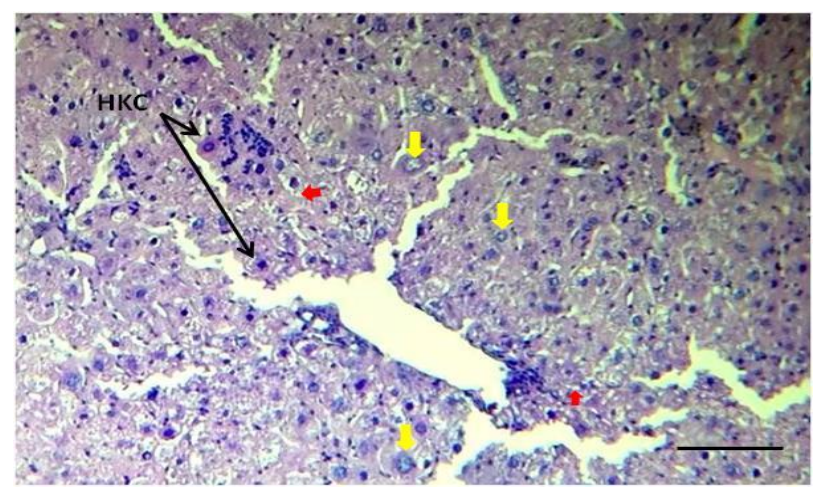

Fig.5. Photomicrograph of a liver section from the detergenttreated group $(3 \mathrm{~g} / \mathrm{Kg}$ for $15 \mathrm{~min})$ showing marked hepatocellular cytoplasmic vacuolation (yellow arrows), nuclear pyknosis (red arrows) and Kupffer cell hyperplasia (black arrows) $((\mathrm{H} \& \mathrm{E}$, Scale Bar $=50 \mu \mathrm{m})$.

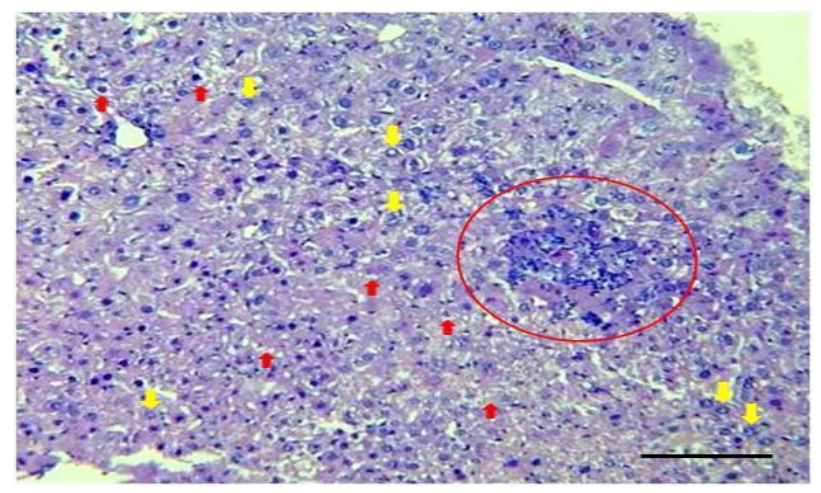

Fig.6. Photomicrograph of a liver section from the detergenttreated group (3 $\mathrm{g} / \mathrm{Kg}$ for $15 \mathrm{~min})$ showing marked hepatocellular cytoplasmic vacuolation (red arrows), nuclear pyknosis (yellow arrows)and focal aggregation of

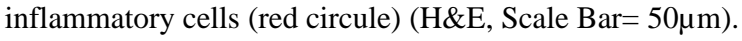




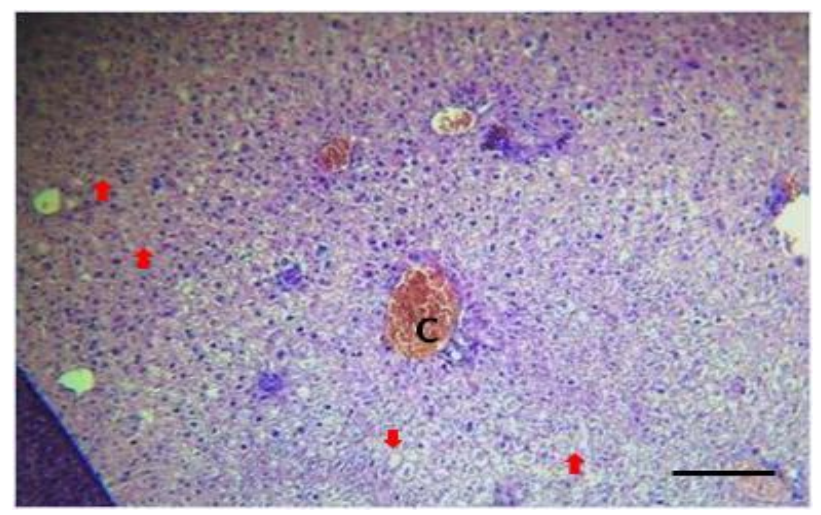

Fig.7. Photomicrograph of a liver section from the detergenttreated group (3 $\mathrm{g} / \mathrm{Kg}$ for $30 \mathrm{~min}$ ) showing blood vessel congestion (C), cloudy swelling, severe narrowing of sinusoids (red arrows) and marked nuclear pyknosis associated with satellitosis $(\mathrm{H} \& \mathrm{E}$, Scale Bar $=100 \mu \mathrm{m})$.

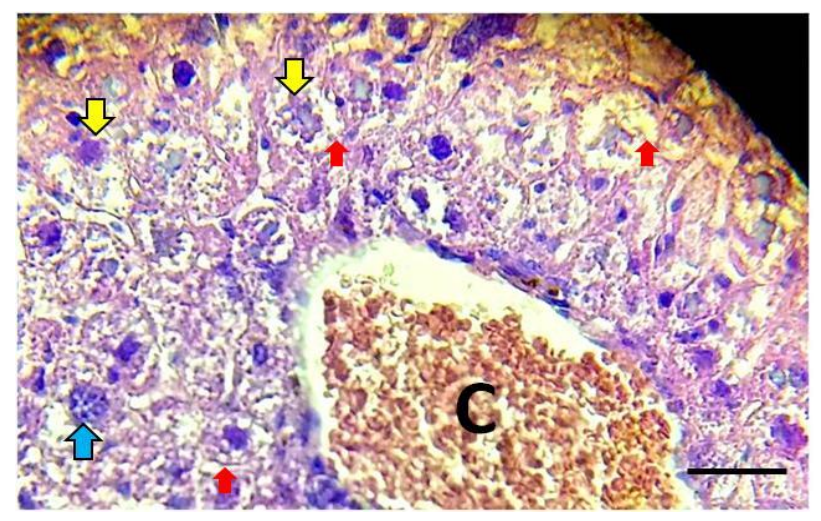

Fig.8. Photomicrograph of a liver section from the detergenttreated group (3 $\mathrm{g} / \mathrm{Kg}$ for $30 \mathrm{~min}$ ) showing blood vessel congestion $\mathrm{C}$, marked cytoplasmic vacuolation (red arrows) (ballooning degeneration), severe narrowing of sinusoids and nuclear pyknosis and karyorrhexix (yellow arrows). (H\&E, Scale Bar= 25 $\mu \mathrm{m})$. 


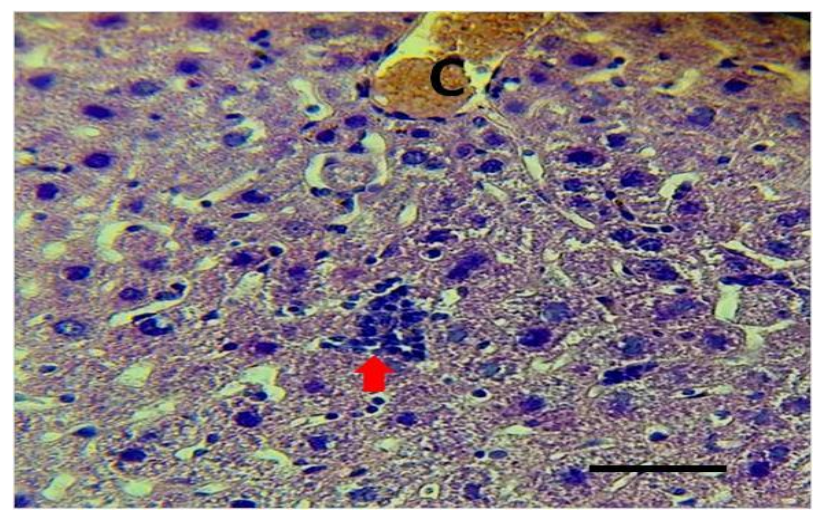

Fig.9. Photomicrograph of a liver section from the detergenttreated group $(4.5 \mathrm{~g} / \mathrm{Kg}$ for $15 \mathrm{~min})$ showing blood vessel congestion, marked cytoplasmic vacuolation, narrowing of sinusoids, nuclear pyknosis and satellitosis (phagocytosis of necrotic liver cells) and infiltration of lymphocytes (red arrow) $(\mathrm{H} \& \mathrm{E}$, Scale $\mathrm{Bar}=50 \mu \mathrm{m})$

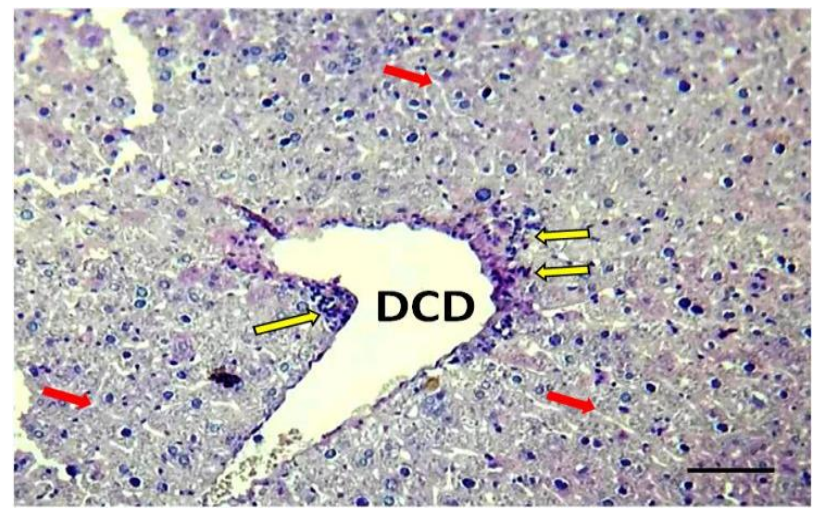

Fig.10. Photomicrograph of a liver section from the detergenttreated group $(4.5 \mathrm{~g} / \mathrm{Kg}$ for $30 \mathrm{~min})$ showing cytoplasmic vacuolation, narrowing of sinusoids (red) and nuclear pyknosis, perivascular lymphocytic infiltration (yellow arrows) and Dilation of Central Hepatic Vein (DCV). (H\&E, Scale Bar $=100 \mu \mathrm{m})$. 


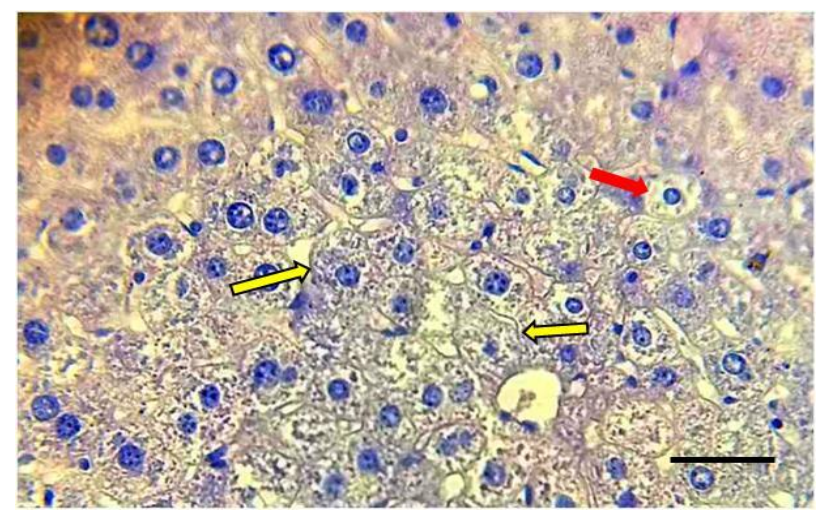

Fig.11. Photomicrograph of a liver section from the detergenttreated group $(1.5 \mathrm{~g} / \mathrm{Kg}$ for $1-2 \mathrm{~min})$ showing marked hepatocellular swelling with pallor cytoplasm (yellow arrows) due to cytoplasmic vacuolation (hydropic degeneration) (red arrows) resulting in severe narrowing of sinusoids (H\&E, Scale Bar= 25 $\mu \mathrm{m})$.

\section{Discussion}

From the above results, it is apparent that the livers damaged at the cellular levels due to the effects of detergent. The present findings seem to be consistent with other research that found the pathological effects of the detergents as a result of the cytotoxic agents inside the detergent solutions which caused multi-organ injuries [14] [15]. The most interesting finding that the early pathologic changes induced in the liver of mice by detergent included marked cloudy swelling with pallor cytoplasm with infiltration of mononuclear inflammatory cells. This finding is in agreement with Kadi et al. [16] and Ogundiran et al. [5] findings which showed enlargement of the spleen and liver with vacuolation of hepatocyte, oedema, cellular infiltration and cellular necrosis. This result supports the findings of Gholami et al. [17] and Ogundiran et al. [18] that were reported, that the ingestion of detergent solutions can cause multi-organ damage leads to nervous system disorders, respiratory illness, birth defects, cancer and even the dead. A possible explanation for this might be the toxic effects of some detergent contents such as anionic surfactant and traces amount of heavy metals that have the accumulative effects on affected organs those failures for detoxifying the toxic products from the tissues. Furthermore, the result is in line with Akanji et al. [19] and UaboiEgbenni et al. [20] both reported severe pathological changes in some vital organs of animals and even plants that exposed to the detergent, continuously. However, this study did not found such diseases like cancer and asthma which have been suspected by some researchers [21], probably due to the short period of the experimental design.

In this study histology alterations were identified within the hepatocytes, maybe have been resulted of various irregular central vein shape, ballooning degeneration or cytoplasmic vacuolation and infiltration of mononuclear inflammatory cells may be attributed to the cloudy swelling associated with narrowing of the sinusoids and accumulation of lipids and glycogen due to livers dysfunction as a result of exposure to the toxic agents. This is in confirming the findings of Fanta et al. [22] who worked with catfishes exposed to the organophosphate pesticides, which were related to the normal metabolic liver function. Furthermore, Pacheco and Santo [23] also described hepatocellular cytoplasmic vacuolation with nuclear pyknosis and Kupffer cell hyperplasia as a signal to the process of degeneration which suggested metabolic damage possibly has related to water exposed to the detergents or soaps. 
The cells of liver parenchyma started degradation resulting in severe narrowing of sinusoids with marked hepatocellular necrosis as indicated by the nuclear karyorrhexis and karyolysis in the groups receiving a high dose of detergent agents and the groups that ingested foods soaked for a long time in detergents. This also accords with earlier observations, which showed signs of focal necrosis and fatty degeneration associated with exposure to the mixtures of copper and zinc which has reported for polychlorinated biphenyls [24], lead and mercury [25] [26]. In addition, the results in the current study illustrated a Kupffer cell hyperplasia associated with satellitosis (phagocytosis of the necrotic hepatocytes), dilation of central vein and vascular congestion. Some authors [16] [27] [28] have speculated that to uricase enzyme disturbance in the liver after exposure to the high concentrations of detergents which increase the level of the uric acid in the body which led to vascular congestion and central vein dilation. The results mentioned in this study have shown more severe alterations than those have observed grossly when exposed to each chemical substance separately; this because of the effects detergent and other contaminants, especially for metals, which enhanced when mixed to produce the detergents or cleaning agents [29]. In general, therefore, it seems that the effects increased with increasing the concentration and duration of exposure to the detergents.

\section{Conclusion}

This study set out to determine the impact of oral ingested detergents on the livers of experimental animals. It was also shown that detergent solutions are toxic to exposed animals which leads to histopathological changes in their livers. In fact, low concentrations of detergents can induce various histological changes; however, the effects increased with rising concentration and period of exposure to the detergents. The findings of this study suggest that using detergents should handling with a proper way and control or replace detergents in food washing by using natural alternatives without health hazards.

\section{References}

[1] Chun, W.C and H.Z. You, Nonionic surfactant Brij35 effects on toluene biodegradation in a composite bead bio-filter. Afr. J. Biotechnol., 8:5406-5414 (2009)

[2] Abulude, F.O. Ogunkoya, R.F. Ogunleye, O. Emidun and A.I. Abulude: Assessment of the content of $\mathrm{Pb}, \mathrm{Cd}, \mathrm{Ni}$ and $\mathrm{Cr}$ in soap and detergent from Akure. Nigeria. Res. J. Environ. Toxicol., 1:102-104 (2007)

[3] Redmond, W.A.: Detergent: Encarta Microsoft corporation (DVD). USA (2011)

[4] Sani A, Shehu A.: Determination of Some Heavy Metals Concentration in Selected Detergents Used in Kano Metropolis, Nigeria. Environ Toxicol Stud J. 2:4 (2018)

[5] Ogundiran, M.A., O.O. Fawole, S.O. Adewoye and T.A. Ayandiran: Toxicological impact of detergent effluent on juvenile of African Catfish (Clarias gariepinus) (Buchell 1822). Agric. Bio. J. North Am., 1: 330-342 (2010)

[6] Ezemonye, L. and A. Enuneku: Evaluation of acute toxicity of cadmium and lead to amphibian tadpole (Toad: Bufo maculatus and frog: Ptychadena bibroni) and frog. J. Aquat. Sci., 20: 3336 (2005)

[7] DPR : Environmental Guidelines and standards for the petroleum industry in Nigeria. Ministry of Petroleum Resources, Lagos, UK., pp: 35-76 (1991)

[8] Easy and Essay: Effects of laundry detergent on the environment. http://ezessay.blogspot.com/2007/12/effects-of-laundry-detergent-on.html (2007)

[9] Hasan, F., A.I. Shah, S. Javed and A. Hammed: Enzymes used in detergent: Lipases. Afr. J. Biotechnol., 9: 4836-4844 (2010)

[10] Ojo, O.A. Oso.: Biodegradation of synthetic detergents in wastewater . Afr. J. Biotechnol. 8: 1090-1109 (2009) 
[11] Warne, M.J .St and A.D. Schifko: Toxicity of laundry detergent components to a freshwater cladoceran and their contribution to detergent toxicity. Ecotoxicol. Safety. 44: 196-206 (1999)

[12] Ogunbileje, J.O. and O.M. Akinosun: Biochemical and hematological profile in Nigeria cement factory workers. Res.J. Environ.Toxicol. (2011)

[13] Wadaan, M.A.M. and M. Mubarak: Blood chemistry changes as evidence of the toxic effects of anionic surfactant sodiumdodisulfate. Asian J. Scientific Res. 2: 113-118 (2009)

[14] Ayandiran, T.A., Fawole, O.O. Adewoye, S.O. and Ogundiran, M.A.: Bio-concentration of metals in the body muscle and gut of Clarias gariepinus exposed to sub-lethal concentrations of soap and detergent effluent. J. Cell Anim. Biol., 3: 113-118 (2009)

[15] Yahaya, T., J. Okpuzor, EO. Oladele: Investigation of toxicity of detergents.Journal of Environmental Science and Technology 4 (6): 638-645 (2011)

[16] Kadi, F. , Bénali, A. , Bénali, M. and Belbraouet, S.: Effect of Sodium Metabisulphite on Blood Metabolic Status of Wistar Rats. Food and Nutrition Sciences, 5, 1529-1537 (2014)

[17] Gholami, M., S.M.R. Fatemi, M. Falahi, A. Esmaili and A. Mashinchiyan: Effects of heavy metals (copper and cadmium) and detergent (LAS) on white fish fry Rutilus frisii Kutum. Res. J. Environ. Toxicol., 4: 231-236 (2010)

[18] Ogundiran, M.A., O.O. Fawole, S.O. Adewoye and T.A. Ayandiran: Pathologic lesion in the gills of Clarias gariepinus exposed to sub-lethal concentrations of soap and detergent. J. Cell Anim. Biol., 3: 78-82 (2009)

[19] Akanji, M.A., Olagoke, O.A. Oloyede, O.B.: Effects of chronic consumption of metalbisulphate on the integrity of rat liver cellular system. Toxicology, 81: 173-179 (1993)

[20] Uaboi-Egbenni, P.O., P.N. Okolie, O.E. Adejuyitan, A.O. Sobande and O. Akinyemi: Effects of industrial effluents on the growth and anatomical structures of Abelmoschus esculentus [Okro]. Afr. J. Biotechnol., 8: 3251-3260 (2009)

[21] Kassem, N.: Allergens and toxins in laundry detergents: Synthetic ingredients that are harmful to people and the environment (2010). (Accessed on 3rdFebuary, 2015) Available: http://organizedwisdom.com/allergens-and-toxins-in-laundry-detergentssynthetic-ingredientthat-are-harmful-topeople.

[22] Fanta, E., F. S. Rios, S. Romão, A. C. C. Vianna \& S. Freiberger: Histopathology of the fish Corydoras paleatus contaminated with sublethal levels of organophosphorus in water and food. Ecotoxicology and Environmental Safety, 54: 119-130 (2003)

[23] Pacheco, M. and M. A. Santos: Biotransformation, genotoxic and histopathological effects of environmental contaminants in European eel (Anguilla anguilla L.). Ecotoxicology and Environmental Safety, 53: 331-347 (2003)

[24] Chang, S., V. S. Zdanowicz and R. A. Murchelano: Associations between liver lesions in winter flounder (Pleuronectes americanus) and sediment chemical contaminants from north-east United States estuaries. Journal of Marine Sciences, 55: 954-969 (1998)

[25] Srivastava Savita, AK Srivastava, Srivastava Sudhir, GK Patnaik, BN Dhawan: Effect of picroliv and silymarin on liver regeneration in rats.The Indian Journal of Pharmacology 26(1): 19-22 (1994)

[26] Paris-Palacios, S., S. Biagianti-Risbourg and G. Vernet: Biochemical and (ultra)structural hepatic perturbations of Brachyodanio rerio (Teleostei, Cyprinidae) exposed to two sublethal concentrations of cooper sulfate. Aquatic Toxicology, 50: 109-124 (2000)

[27] Regoli, F. and Winston, G.W.: Quantification of Total Oxidant Scavenging Capacity of Antioxidants for Peroxynitrite, Peroxyl Radicals, and Hydroxyl Radicals. Toxicology and Applied Pharmacology, 156, 96-105 (1999) 
[28] Wu, X.W., Muzny, D.M., Lee, C.C. and Caskey, C.T.: Two Independent Mutational Events in the Loss of Urate Oxidase during Hominoid Evolution. Journal of Molecular Evolution, 34, 7884 (1992)

[29] Langiano CV, Martinez CB.: Toxicity and Effects of a Glyphosate-Based Herbicide on the Neotropical Fish Prochilodus Lineatus. Comparative Biochemistry and Physiology Part C: Pharmacology, Toxicology and Endocrinology; 147:222-231 (2008) 